\title{
Analisis Sistem Informasi Geografis (SIG) untuk Penentuan Lokasi Homestay Wisata (Studi Kasus: Desa Sendang, Kecamatan Wonogiri, Kabupaten Wonogiri)
}

\author{
Geographic Information System (GIS) Analysis for Determination of Tourist Homestay Locations (Case \\ Study: Sendang Village, Wonogiri Sub-District, Wonogiri District) \\ Nafisa Andika Putri', Waljiyanto ${ }^{2}$
}

${ }^{1}$ Alumni Program Studi Sarjana Departemen Teknik Geodesi FT-UGM, Indonesia

2 Departemen Teknik Geodesi FT-UGM, Indonesia

Penulis Korespondensi: Nafisa Andika Putri | Email: nafisaap25@gmail.com

Diterima (Received): 19/08/2020 Direvisi (Revised): 11/10/2020 Diterima untuk Publikasi (Accepted): 12/10/2020

\begin{abstract}
ABSTRAK
Desa Sendang adalah sebuah desa wisata yang pada objek-objek wisatanya sering diadakan kegiatan bertaraf nasional dan internasional yang mengundang wisatawan dari berbagai daerah. Namun, jumlah wisatawan yang berkunjung tidak diimbangi dengan jumlah penginapan yang cukup, sehingga Pemerintah Desa Sendang memiliki rencana pengembangan sarana prasarana pariwisata berupa homestay wisata. Oleh karena itu, diperlukan penentuan lokasi yang sesuai untuk homestay berdasarkan beberapa kriteria dan analisis Sistem Informasi Geografis (SIG). Penelitian ini dilakukan untuk menganalisis lokasi-lokasi yang sesuai untuk homestay wisata dan mengevaluasi kesesuaiannya dengan Peta Rencana Tata Ruang Wilayah (RTRW). Penentuan lokasi homestay dilakukan menggunakan analisis SIG metode Analytic Hierarchy Process (AHP), di mana analisis SIG mencakup proses overlay dengan Peta RTRW. Kriteria yang digunakan dalam penelitian adalah penggunaan lahan dan beberapa kriteria yang mengacu pada ASEAN Homestay Standard. Metode AHP dilakukan untuk mendapatkan bobot masing-masing kriteria hingga sub-sub-kriteria dan dilakukan dengan mewawancarai tiga orang narasumber. Ketiga narasumber tersebut adalah sekretaris desa Desa Sendang, staff Seksi Destinasi Pariwisata Dinas Kepemudaan dan Olahraga dan Pariwisata (Dispora) Kabupaten Wonogiri, dan Kepala Seksi Perencanaan Tata Ruang Dinas Perumahan Rakyat Dan Kawasan Permukiman Dan Pertanahan (Dispera dan KPP) Kabupaten Wonogiri. Perhitungan bobot dilakukan dengan perangkat lunak Expert Choice 11 hingga didapatkan nilai bobot dengan rasio konsistensi <0,1. Proses analisis SIG metode AHP ini menunjukkan terdapat 120,51 hektar lahan sesuai/S1 untuk lokasi homestay yang tersebar pada 24 RT di 11 dusun. Sedangkan, overlay lahan S1 dengan Peta RTRW menunjukkan terjadinya pengurangan lahan sesuai, menjadi 68,8 hektar yang tersebar pada 23 RT di 11 dusun.
\end{abstract}

Kata Kunci: Analytic Hierarchy Process (AHP), Expert Choice 11, homestay, Sistem Informasi Geografis (SIG)

\begin{abstract}
Sendang Village is a tourism village where many national and international events were held in the tourism attraction sites and attracted many tourists from various regions. However, there weren't enough lodgings for the tourists, hereby the Sendang Officials wanted to develop tourism infrastructure in the form of tourist homestays. Therefore, it is necessary to determine suitable locations for homestays using several citeria with GIS analysis. This research was conducted to analyze suitable locations for homestays and evaluate its suitability with the Regional Spatial Planning Map. Determination of the locations was done using Geographic Information System (GIS) analysis with Analytic Hierarchy Process (AHP) method. The criteria used in this study were land use and several criteria that refer to ASEAN Homestay Standard. The AHP method was used to obtain the weight of each criterion down to the sub-sub-criteria and was done by interviewing three interviewees. The interviewees were the secretary of Sendang Village, Department of Youth and Sports and Tourism of Wonogiri Regency staff, and the Head of Spatial Planning of Department of Public Housing, Resettlement, and Land Administration Wonogiri. Weight calculation was done using Expert Choice 11 software to obtain a weight value with a consistency ratio <0,1. Meanwhile, The GIS analysis was done using ArcGIS 10.5 and QGIS 3.8. The GIS AHP analysis shows that there is a total of 120,51 hectares of suitable area/S1 for homestays over 24 neighbourhoods in 11 hamlets. Meanwhile, the overlay of S1 with the Regional Spatial Planning Map shows that there is a reduction in suitable areas to a total of 68,8 hectares over 23 neighbourhoods in 11 hamlets.
\end{abstract}

Keywords: Analytic Hierarchy Process (AHP), Expert Choice 11, Geographic Information Systems (GIS), homestays 


\section{Pendahuluan}

Pariwisata merupakan salah satu sektor industri yang memiliki potensi besar untuk dikembangkan (Prafitri \& Damayanti, 2016). Perkembangan pariwisata di negara yang sedang berkembang seperti Indonesia diharapkan dapat meningkatkan perekonomian dan kesejahteraan masyarakat sekitar (Evita et al., 2012). Di Indonesia, tren perkembangan pariwisatanya adalah berbasis desa wisata. Desa wisata merupakan suatu istilah bagi desa yang menawarkan suasana asli pedesaan dan memiliki komponen kepariwisataan yang dapat dikembangkan (Triambodo, 2014).

Salah satu desa wisata di Indonesia adalah Desa Sendang yang terletak di Kecamatan Wonogiri, Kabupaten Wonogiri, Provinsi Jawa Tengah. Penetapan Desa Sendang sebagai desa wisata sendiri diatur dalam Keputusan Kepala Dinas Kepemudaan dan Olahraga dan Pariwisata (Disporapar) Kabupaten Wonogiri Nomor 143 Tahun 2017. Topografi Desa Sendang berupa dataran tinggi/pegunungan dengan ketinggian \pm 621 meter di atas permukaan laut (Pemerintah Desa Sendang, 2019). Dikarenakan kondisi geografis tersebut, dapat ditemui berbagai wisata alam dan juga lokasi untuk olahraga ekstrim seperti Puncak Joglo, Watu Cenik, dan Menara Pandang. Selain itu, terdapat objek wisata lain yang terkenal, yaitu, Waduk Gajah Mungkur. Di objek-objek wisata tersebut, sering diadakan kegiatan bertaraf nasional maupun internasional yang mendatangkan banyak wisatawan lokal maupun asing.

Banyaknya wisatawan yang berkunjung ke Desa Sendang tidak diimbangi dengan jumlah penginapan yang cukup, sehingga, wisatawan terpaksa menginap di luar Desa Sendang. Terkait hal tersebut, Desa Sendang sebagai desa wisata memiliki rencana pengembangan sarana dan prasarana pariwisata yang sudah dituliskan dalam Rencana Pembangunan Jangka Menengah (RPJM) Desa. Rencana ini sejalan dengan peraturan yang dituliskan dalam Keputusan Kepala Dispora Kabupaten Wonogiri Nomor 143 Tahun 2017 bahwa pemerintah desa diharapkan dapat mendukung kegiatan pengembangan desa wisata. Pengembangan sarana dan prasarana pariwisata ini lebih khususnya mengenai homestay wisata.

Homestay wisata adalah sebuah penginapan bagi wisatawan yang memiliki konsep sewa kamar rumah milik warga (Raharjana, 2012). Homestay menawarkan wisatawan pengalaman untuk dapat merasakan gaya hidup di suatu desa bersama komunitas lokal. Jenis pengalaman yang ditawarkan homestay tersebut menjadi sangat populer di kalangan wisatawan asing, sehingga, Desa Sendang memilih pengembangan penginapan berupa homestay wisata. Selain itu, adanya homestay juga dapat meningkatkan kualitas hidup lokal melalui beberapa hal seperti meningkatan pendapatan dan mendukung budaya lokal (ASEAN, 2016).

Dalam pelaksanaannya, perlu dilakukan penentuan lokasi yang sesuai untuk homestay. Namun, saat ini belum ada penelitian mengenai lokasi yang sesuai untuk homestay di Desa Sendang sehingga, perlu dilakukan analisis SIG metode AHP.

\section{Penelitian Sebelumnya}

Di Indonesia, Menurut Ketua Tim Percepatan Homestay Kementerian Pariwisata, Anneke Prasyanti, pelaksanaan pengembangan homestay oleh Kementerian Pariwisata mengacu pada kepada standar homestay ASEAN/ASEAN Homestay Standard (Petriella, 2019). Berdasarkan pernyataan tersebut, syarat-syarat yang digunakan dalam proses analisis untuk menentukan lokasi homestay di Desa Sendang mengacu pada ASEAN Homestay Standard.

Penentuan lokasi homestay ini tentunya melibatkan banyak syarat/kriteria (multi kriteria), sehingga penelitian menggunakan metode Analytic Hierarchy Process (AHP) yang diintegrasikan dengan analisis Sistem Informasi Geografis (SIG). AHP adalah metode pengambilan keputusan yang melibatkan banyak kriteria dan AHP dapat membantu menentukan tingkat kepentingan tiap kriteria dengan penentuannya menggunakan pendapat para ahli (Saaty \& Vargas, 2012; Oksaping dkk. 2019). Sedangkan, analisis kesesuaian lahan untuk suatu penggunaan dapat dilakukan dengan analisis SIG karena permasalahan tersebut termasuk permasalahan geospasial (Parry et al., 2018; Adiyaksa \& Nugroho, 2020; Astrisele \& Santosa, 2019). Oleh karena itu, analisis SIG dapat digunakan untuk menentukan lokasi yang sesuai untuk homestay.

Analisis kesesuaian lahan menggunakan analisis SIG metode AHP sudah dilakukan oleh Hidayati et al. (2015); Kadriansari et al. (2017); Siagian et al. (2016). Ketiganya menggunakan AHP untuk menentukan nilai bobot masingmasing parameter, di mana penentuannya melibatkan pendapat ahli.

Dalam menghitung nilai bobot metode AHP, perhitungan yang dilakukan secara manual memiliki kemungkinan terjadi human errors yang lebih tinggi, sehingga salah satu solusinya adalah perhitungan dilakukan dengan bantuan perangkat lunak. Pada penelitian oleh Yunus et al. (2013), digunakan perangkat lunak Expert Choice 11. Perangkat lunak ini dipilih karena mudah digunakan dan dipahami. Selain itu, penelitian mengenai evaluasi lahan permukiman Kota Manado yang dilakukan oleh Solang et al. (2017) juga menggunakan perangkat lunak Expert Choice 11 untuk perhitungan bobot. Kriteria yang digunakan ada delapan yaitu, kemiringan lereng, kerawanan bencana, jenis tanah, jarak dari jalan, kepadatan penduduk, penggunaan lahan, peruntukan kawasan, dan administrasi kecamatan. Perhitungan bobot menggunakan perangkat lunak Expert Choice 11 menghasilkan konsistensi 0,08 dimana nilai tersebut sudah termasuk konsisten.

Parameter-parameter yang sudah ditentukan bobotnya kemudian diolah dengan operasi overlay dan reklasifikasi dalam perangkat lunak ArcGIS. Hasil dari overlay tiap-tiap parameter kemudian dibandingkan dengan Peta Rencana 
Tata Ruang Wilayah (RTRW) untuk dinilai kesesuaiannya. Menurut Widiyastuti et al. (2019), hasil analisis dibagi menjadi 4 kelas kesesuaian yaitu, sangat sesuai (S1), cukup sesuai (S2), kurang sesuai (S3), dan tidak sesuai (N).

Hasil analisis tersebut yang kemudian menjadi Peta Kesesuaian Lahan untuk Lokasi Homestay Wisata, di mana Peta tersebut dapat membantu pemerintah Desa Sendang dalam membuat keputusan terkait penentuan lokasi homestay wisata di Desa Sendang. Keputusan yang dibuat oleh pemerintah desa diharapkan dapat mewujudkan homestay yang aman dan baik.

\section{Data dan Metodologi}

\subsection{Data dan Lokasi}

Penelitian dilakukan di Desa Sendang, Kecamatan Wonogiri, Kabupaten Wonogiri. Secara geografis, Desa Sendang berada pada $7^{\circ} 50^{\prime} 6^{\prime \prime}-7^{\circ} 51^{\prime} 54^{\prime \prime}$ Lintang Selatan dan $110^{\circ} 52^{\prime} 12^{\prime \prime}-110^{\circ} 55^{\prime} 19,2^{\prime \prime}$ Bujur Timur. Data-data yang digunakan dalam penelitian ini yaitu Digital Elevation Model Nasional (DEMNAS) dengan resolusi spasial 8,1 meter yang diunduh dari http://tides.big.go.id/DEMNAS/ Peta Indikator Kumuh Desa Sendang.jpg dari pemerintah Desa Sendang, Peta Rencana Tata Ruang Wilayah (RTRW) Kabupaten Wonogiri Tahun 2011-2031 dari Dinas Perumahan Rakyat dan Kawasan Permukiman dan Pertanahan (Dispera dan KPP) Kabupaten Wonogiri, koordinat X dan Y lokasi wisata Desa Sendang dari Google Earth Pro, dan terakhir adalah data kuesioner pembobotan kriteria dari hasil wawancara tiga ahli.

\subsection{Metodologi}

Secara umum, pelaksanaan penelitian ini dibagi menjadi 5 tahap yaitu tahap persiapan awal dan pengumpula data, penentuan nilai bobot, persiapan data untuk overlay, pengolahan dan analisis data (overlay), dan penyajian hasil. Tahapan pelaksanaan tersebut digambarkan dalam diagram alir yang ditunjukkan pada Gambar 2.1.

\subsubsection{Persiapan Awal dan Pengumpula Data}

Tahap persiapan awal dan pengumpulan data ini mencakup identifikasi permasalahan dan studi literatur. Tahap studi literatur dilakukan untuk menentukan kriteria dan metode yang akan digunakan dalam penelitian, sehingga, menghasilkan produk peta kesesuaian lahan yang akurat.

Pada tahap ini juga dilakukan pengumpulan data dan persiapan software yang diperlukan untuk proses pengolahan data dan analisis. Data-data yang dikumpulkan adalah data-data terkait kriteria yang sebelumnya telah ditentukan pada proses studi literatur. Sedangkan, persiapan software pada tahap ini dilakukan untuk mempersiapkan software Expert Choice 11, ArcGIS dan QGIS.

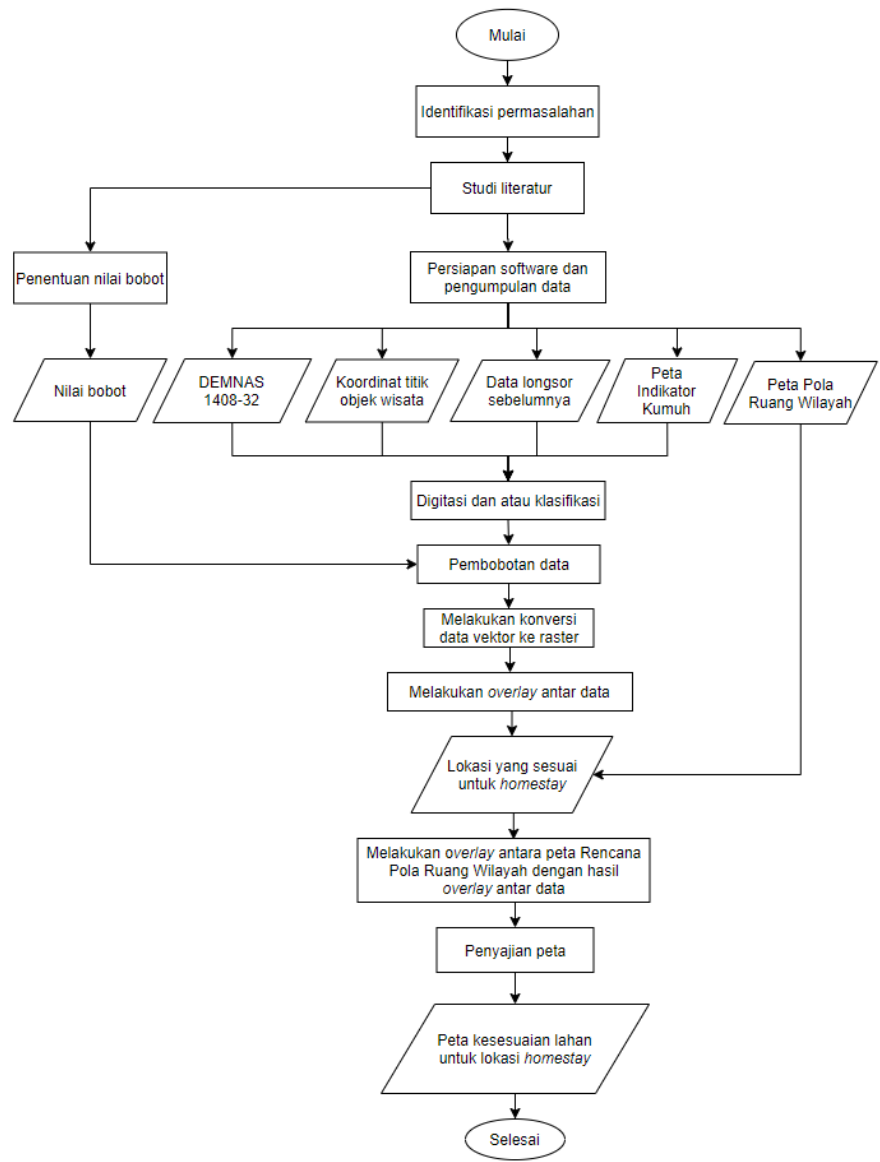

Gambar 2.1 Diagram alir pelaksanaan penelitian

\subsubsection{Penentuan Nilai Bobot}

Penentuan nilai bobot dilakukan untuk mendapatkan nilai bobot yang akan digunakan pada tahap pengolahan dan analisis data (overlay). Pada tahap penentuan nilai bobot, terdapat 3 kegiatan utama. Kegiatan utama tersebut adalah penyusunan hierarki, melakukan perbandingan berpasangan, dan menghitung nilai bobot.

Penyusunan hierarki dilakukan untuk menguraikan suatu permasalahan menjadi ke dalam bentuk hierarki dari tingkatan tertinggi hingga tidak mungkin diuraikan lagi. Tingkatan tertinggi adalah goal (tujuan) yang merupakan lokasi yang sesuai untuk pengadaan homestay. Tingkatan kedua adalah kriteria penentuan lokasi yang sesuai untuk homestay. Tingkatan ketiga adalah subkriteria yang merupakan uraian lebih detail dari kriteria. Tingkatan keempat adalah sub-sub-kriteria yang merupakan uraian lebih detail dari sub-kriteria. Tingkatan terakhir adalah alternatif yang berupa lokasi-lokasi alternatif untuk homestay.

Perbandingan berpasangan dilakukan untuk melakukan perbandingan prioritas antar kriteria, subkriteria, dan sub-sub-kriteria berdasarkan hierarki yang telah disusun sebelumnya. Terlebih dahulu harus dibuat matriks perbandingan berpasangan dalam bentuk kuesioner cetak. Kemudian, pada kuesioner cetak dilakukan pemberian nilai skala prioritas oleh ahli. 
Menurut (Bhushan \& Rai, 2004), nilai skala prioritas berada pada rentang 1 sampai 9 dengan definisi setiap nilai seperti yang disebutkan pada Tabel 2.1.

Tabel 2.1 Skala penilaian AHP (Bhushan \& Rai, 2004)

\begin{tabular}{cl}
\hline $\begin{array}{c}\text { Tingkat } \\
\text { kepentingan }\end{array}$ & \multicolumn{1}{c}{ Definisi } \\
\hline 1 & $\begin{array}{l}\text { Kedua elemen sama penting } \\
\text { Elemen yang satu sedikit lebih penting dari } \\
\text { elemen lainnya }\end{array}$ \\
5 & $\begin{array}{l}\text { Elemen yang satu lebih penting dari elemen } \\
\text { lainnya }\end{array}$ \\
7 & $\begin{array}{l}\text { Elemen yang satu jelas lebih penting dari } \\
\text { elemen lainnya }\end{array}$ \\
9 & $\begin{array}{l}\text { Elemen yang satu mutlak lebih penting dari } \\
\text { elemen lainnya } \\
\text { Nilai antara dua tingkat yang berdekatan }\end{array}$ \\
\hline
\end{tabular}

Setelah pemberian nilai prioritas selesai dilakukan oleh ketiga ahli, dilakukan proses perhitungan nilai bobot. Proses ini dilakukan untuk mendapatkan nilai bobot kriteria, sub-kriteria, dan sub-sub-kriteria. Perhitungan nilai bobot dilakukan dengan menggunakan perangkat lunak Expert Choice 11. Dikarenakan pada penelitian ini melibatkan pendapat 3 ahli, maka perlu dihitung nilai ratarata kriteria, sub-kriteria, dan sub-sub-kriteria dari penilaian ketiga ahli tersebut. Nilai rata-rata dihitung dengan menjumlahkan nilai skala prioritas ketiga ahli dan kemudian hasil penjumlahannya dibagi dengan 3. Nilai rata-rata inilah yang kemudian diolah menggunakan perangkat lunak Expert Choice 11 sehingga didapatkan nilai bobot. Nilai bobot ini dapat digunakan pada tahap selanjutnya jika memiliki Consistency Ratio (CR) <0,1.

\subsubsection{Persiapan Data untuk Overlay}

Tahap ini dilakukan untuk mempersiapkan data-data guna keperluan overlay. Pada tahap ini, terdapat 3 kegiatan utama. Kegiatan utama tersebut adalah digitasi dan atau klasifikasi, pembobotan data, dan konversi data vektor ke raster.

Proses digitasi dan atau klasifikasi dilakukan pada setiap data yang menjadi input dalam proses overlay. Pada proses ini, data-data yang terkumpul diolah dan diklasifikasikan menjadi beberapa kelas. Pada data yang masih dalam format *.jpg, seperti Peta Indikator Kumuh Desa Sendang, perlu dilakukan digitasi untuk mendapatkan data shapefile-nya (penggunaan lahan, jaringan jalan, batas kecamatan, batas desa, batas dusun, dan batas RT). Data yang tidak perlu melalui proses digitasi seperti DEMNAS diolah menggunakan tools Slope pada perangkat lunak QGIS untuk menghasilkan raster slope. Kemudian, proses klasifikasi meliputi pengklasifikasian suatu nilai dan juga suatu rentang yang memanfaatkan tools Reclassify, tools multiple ring buffer dan editing tabel atribut.

Setiap data yang telah diklasifikasikan kemudian diberi nilai bobotnya masing-masing. Setiap data memiliki nilai bobot yang berbededa-beda. Pembobotan data vektor dilakukan dengan membuat kolom baru bernama "Bobot" pada tabel atribut masing-masing data. Kolom bobot tersebut kemudian diisi dengan nilai bobot masing-masing kelas. Pembobotan data raster dilakukan dengan tools Reclassify. Nilai piksel tiap kelas raster diubah sesuai nilai bobotnya.

Setelah seluruh data diberi nilai bobot, untuk data yang masih berupa data vektor perlu dikonversi menjadi data raster. Konversi dilakukan menggunakan conversion tools Polygon to Raster pada ArcGIS 10.5. Setiap konversi dilakukan dengan mempertahankan nilai bobot masingmasing parameter, atau dengan kata lain, value field yang dipilih adalah kolom "Bobot". Hasil proses konversi adalah data raster baru dengan satuan terkecil piksel yang berisi informasi unik berupa nilai bobot.

\subsubsection{Pengolahan dan Analisis Data (Overlay)}

Proses ini dilakukan untuk menentukan lokasi yang sesuai untuk homestay wisata. Proses overlay ini dilakukan menggunakan Raster Calculator pada Map Algebra yang terdapat di perangkat lunak ArcGIS 10.5. Proses overlay dilakukan antar data pada tingkatan hierarki yang sama.

Proses overlay ini pertama kali dilakukan pada tingkatan hierarki yang nilai piksel rasternya adalah nilai bobot dari tingkatan terendah. Pada penelitian ini, overlay dilakukan pertama kali pada tingkat sub-kriteria. Hal ini dikarenakan nilai piksel raster sub-kriteria adalah nilai bobot dari tingkat terendah, yaitu sub-sub-kriteria. Hasil dari overlay antar sub-kriteria ini adalah raster kriteria yang mana raster tersebut perlu di-overlay dengan raster kriteria lainnya untuk menghasilkan Peta Kesesuaian Lahan untuk Lokasi Homestay Wisata. Proses overlay yang dilakukan tersebut merupakan suatu proses matematis yang dilakukan pada data raster sehingga didapatkan total nilai akhir bobot. Total nilai akhir bobot tersebut yang menjadi dasar dalam menentukan tingkat kesesuaian suatu lokasi. Rumus yang digunakan dalam proses overlay ini menurut Pahlavani et al. (2017) adalah rumus 1.

$$
f(x)=\sum_{l=1}^{m} V_{l i} W_{l}
$$

\section{Keterangan: \\ m : jumlah raster \\ Vli : nilai lokasi i pada raster \\ $\mathrm{Wl}$ : nilai bobot raster 1}

Total nilai akhir bobot yang semakin besar menunjukkan bahwa suatu lahan semakin sesuai untuk lokasi homestay wisata, begitupun sebaliknya. Total nilai akhir bobot yang dihasilkan diklasifikasi menjadi 4 kelas yaitu sangat sesuai, cukup sesuai, kurang sesuai, dan tidak sesuai. Klasifikasi tersebut dilakukan menggunakan metode equal interval pada ArcGIS 10.5 atau sama dengan 
rumus interval kelas menurut Umar et al. (2017). Rumus tersebut dapat dilihat pada rumus 2 .

$$
I=\frac{c-b}{k}
$$

Keterangan:

I : besar jarak interval kelas

c: total nilai bobot tertinggi

b: total nilai bobot terendah

$\mathrm{k}$ : jumlah kelas yang diinginkan

Proses overlay antar parameter menghasilkan lokasilokasi yang sesuai dan tidak sesuai untuk homestay wisata. Lokasi-lokasi yang teridentifikasi sesuai tersebut perlu dicek kesesuaiannya terhadap rencana pola ruang di Desa Sendang, sehingga didapatkan lokasi yang sesuai berdasarkan parameter dan juga rencana pola ruang di Desa Sendang. Pengecekan ini dilakukan dengan melakukan proses overlay antara hasil overlay tiap data dengan Peta RTRW. Karena hasil overlay tiap data masih berbentuk raster, terlebih dahulu data tersebut harus dikonversi menjadi data vektor dan kemudian di-overlay dengan data vektor rencana pola ruang di Desa Sendang.

\subsubsection{Penyajian Hasil}

Tahap ini meliputi kegiatan simbolisasi, pembuatan layout, dan pencetakan peta. Proses simbolisasi dan pembuatan layout dilakukan dengan menggunakan perangkat lunak ArcGIS 10.5. Proses simbolisasi dan pembuatan layout dimulai dengan pengaturan warna dan simbol peta yang dilanjutkan dengan mengatur ukuran kertas dan orientasi peta, memasukkan informasi tepi peta, membuat grid, dan mengatur resolusi gambar yang dihasilkan. Resolusi peta yang dipilih dalam penelitian ini yaitu $500 \mathrm{dpi}$.

\section{Hasil dan Pembahasan}

\subsection{Bobot Kriteria Kesesuaian Lokasi untuk Homestay Wisata}

Penentuan nilai bobot kriteria dilakukan dengan mewawancarai 3 narasumber. Narasumber tersebut adalah sekretaris desa Desa Sendang, staff Dinas Kepemudaan dan Olahraga dan Pariwisata (Dispora) Kabupaten Wonogiri, dan Kepala Seksi Perencanaan Tata Ruang Dispera dan KPP Kabupaten Wonogiri. Nilai bobot kriteria yang didapatkan dari pendapat 3 narasumber memiliki CR 0,09 dan ditunjukkan pada Tabel 3.1.

Tabel 3.1 menunjukkan bahwa penggunaan lahan merupakan kriteria dengan nilai bobot tertinggi yaitu sebesar 0,512. Kriteria penggunaan lahan menjadi prioritas utama karena penggunaan lahan dapat menentukan bisa atau tidaknya lahan tersebut digunakan sebagai lokasi homestay. Selain itu, penggunaan lahan juga mempengaruhi total biaya yang harus dikeluarkan oleh pemerintah desa. Pada penelitian ini, kriteria penggunaan lahan di Desa Sendang dibagi menjadi 2 sub-kriteria berdasarkan SNI 7645:2010, yaitu permukiman dan nonpermukiman. Sub kriteria non-permukiman pada penelitian ini mencakup daerah pertanian, daerah bukan pertanian, perairan, dan lahan terbuka. Rasio konsistensi pembobotan pada kriteria ini yaitu sebesar 0,00 dan bobot masing-masing sub-kriterianya dapat dilihat pada Tabel 3.2 .

Tabel 3.1. Bobot kriteria

\begin{tabular}{clc}
\hline No. & \multicolumn{1}{c}{ Kriteria } & Bobot \\
\hline 1. & Penggunaan lahan & 0,512 \\
2. & $\begin{array}{l}\text { Struktur homestay berada pada kondisi } \\
\text { baik, stabil, dan aman }\end{array}$ & 0,215 \\
3. & Jarak dari objek wisata & 0,122 \\
4. & $\begin{array}{l}\text { Lokasi homestay dapat diakses oleh } \\
\text { berbagai transportasi } \\
\text { 5. }\end{array}$ & $\begin{array}{l}\text { Bebas dari tempat perkembangbiakan } \\
\text { nyamuk }\end{array}$ \\
\hline
\end{tabular}

Tabel 3.2 Bobot kriteria penggunaan lahan

\begin{tabular}{clccc}
\hline No & Penggunaan lahan & Bobot & $\begin{array}{c}\text { Luas } \\
\text { (ha) }\end{array}$ & $\begin{array}{c}\text { Persentase } \\
\text { (\%) }\end{array}$ \\
\hline 1. & Permukiman & 0,889 & 246,07 & 23,73 \\
2. & Non-permukiman & 0,111 & 791,09 & 76,27 \\
\hline & Jumlah & $\mathbf{1}$ & $\mathbf{1 0 3 7 , 1 6}$ & $\mathbf{1 0 0}$ \\
\hline
\end{tabular}

Kriteria yang menjadi prioritas nomor dua dengan bobot 0,215 yaitu kriteria bahwa struktur homestay berada pada kondisi baik, stabil, dan aman. Kriteria ini menjadi prioritas nomor dua karena Desa Sendang merupakan desa yang rawan bencana longsor, namun juga merupakan desa wisata. Selain itu, kriteria ini memiliki prioritas di atas kriteria jarak homestay terhadap objek wisata dan jalan karena keamanan wisatawan lebih diutamakan. Kriteria ini memiliki rasio konsistensi 0,00 dan dibagi menjadi 2 sub-kriteria yaitu kemiringan lereng (slope) dan longsor terdahulu. Kedua sub-kriteria tersebut kemudian dijabarkan lagi menjadi sub-sub-kriteria. Hal ini dikarenakan menurut (Nandi, 2007), derajat kemiringan lereng yang besar memiliki potensi longsor yang lebih besar dan menurut (Bachri, 2011), bencana longsor yang pernah terjadi di suatu daerah memiliki kemungkinan untuk terulang di daerah yang sama. Nilai bobot untuk sub-sub-kriteria dari masing-masing sub-kriteria dapat dilihat pada Tabel 3.3 dan Tabel 3.4. Kedua sub-kriteria tersebut kemudian di-overlay untuk membuat raster kriteria struktur homestay berada pada kondisi baik, stabil, dan aman. Raster tersebut dibagi menjadi 5 kategori yang dapat dilihat pada Tabel 3.5. 
Tabel 3.3 Bobot, luas, dan persentase sub-kriteria slope

\begin{tabular}{ccccc}
\hline No. & \multicolumn{1}{c}{ Slope } & Bobot & Luas (ha) & Persentase (\%) \\
\hline 1. & $0-8 \%$ & 0,769 & 30,86 & 2,98 \\
2. & $8-15 \%$ & 0,147 & 96,11 & 9,27 \\
3. & $>15 \%$ & 0,084 & 910,19 & 87,76 \\
\hline & Jumlah & $\mathbf{1}$ & $\mathbf{1 0 3 7 , 1 6}$ & $\mathbf{1 0 0}$ \\
\hline
\end{tabular}

Tabel 3.4 Bobot, luas, dan persentase sub-kriteria longsor

\begin{tabular}{ccccc}
\hline No. & $\begin{array}{c}\text { Longsor } \\
\text { terdahulu }\end{array}$ & Bobot & Luas (ha) & Persentase (\%) \\
\hline 1. & Tidak ada & 0,875 & 944,62 & 91,08 \\
2. & Ada & 0,125 & 92,54 & 8,92 \\
\hline & Jumlah & $\mathbf{1}$ & $\mathbf{1 0 3 7 , 1 6}$ & $\mathbf{1 0 0}$ \\
\hline
\end{tabular}

Tabel 3.5 Luas dan persentase kriteria struktur aman

\begin{tabular}{|c|c|c|c|c|}
\hline No. & Kategori & $\begin{array}{c}\text { Nilai } \\
\text { rentang } \\
\text { bobot }\end{array}$ & $\begin{array}{l}\text { Luas } \\
\text { (ha) }\end{array}$ & $\begin{array}{c}\text { Persentase } \\
\text { (\%) }\end{array}$ \\
\hline 1. & $\begin{array}{l}\text { Sangat } \\
\text { rawan }\end{array}$ & $0,098-0,239$ & 89,96 & 8,67 \\
\hline 2. & Rawan & $0,239-0,380$ & 827,38 & 79,77 \\
\hline 3. & $\begin{array}{l}\text { Cukup } \\
\text { rawan }\end{array}$ & $0,380-0,522$ & 88,96 & 8,58 \\
\hline 4. & $\begin{array}{l}\text { Cukup } \\
\text { aman }\end{array}$ & $0,522-0,662$ & 2,58 & 0,25 \\
\hline 5. & Aman & $0,662-0,804$ & 28,29 & 2,73 \\
\hline \multicolumn{2}{|r|}{ Jumlah } & & 1037,16 & 100 \\
\hline
\end{tabular}

Kriteria yang menjadi prioritas nomor tiga dengan nilai bobot 0,122 dan rasio konsistensi 0,06 yaitu kriteria jarak homestay terhadap objek wisata. Kriteria ini menjadi prioritas nomor tiga karena semakin dekat lokasi homestay terhadap objek wisata, maka semakin mempermudah akses wisatawan. Kriteria ini dibagi ke dalam 4 sub-kriteria yang kemudian masing-masing subkriteria dijabarkan lagi menjadi sub-sub-kriteria jarak. Sub-sub-kriteria jarak ini dibagi menjadi 5 berdasarkan wawancara dengan Sekretaris Desa Sendang. Nilai bobot untuk sub-sub-kriteria dari masing-masing sub-kriteria dapat dilihat pada Tabel 3.6, 3.7, 3.8, dan 3.9. Keempat sub-kriteria tersebut kemudian di-overlay untuk membuat raster kriteria jarak dari objek wisata. Raster tersebut dibagi menjadi 3 kategori yang dapat dilihat di Tabel 3.10.

Tabel 3.6 Bobot, luas, dan persentase sub-sub-kriteria jarak dari Waduk Gajah Mungkur (WGM)

\begin{tabular}{clccc}
\hline No. & $\begin{array}{c}\text { Jarak dari } \\
\text { WGM (m) }\end{array}$ & Bobot & $\begin{array}{c}\text { Luas } \\
\text { (ha) }\end{array}$ & $\begin{array}{c}\text { Persentase } \\
\text { (\%) }\end{array}$ \\
\hline 1. & $0-200$ & 0,506 & 11,92 & 1,15 \\
2. & $201-300$ & 0,263 & 13,6 & 1,31 \\
3. & $301-400$ & 0,128 & 16,17 & 1,56 \\
4. & $401-500$ & 0,062 & 17,4 & 1,68 \\
5. & $>500$ & 0,041 & 978,06 & 94,3 \\
\hline & Jumlah & $\mathbf{1}$ & $\mathbf{1 0 3 7 , 1 6}$ & $\mathbf{1 0 0}$ \\
\hline
\end{tabular}

Tabel 3.7 Bobot, luas, dan persentase sub-sub-kriteria jarak dari Watu Cenik

\begin{tabular}{clccc}
\hline No. & $\begin{array}{c}\text { Jarak dari } \\
\text { Watu Cenik } \\
\text { (m) }\end{array}$ & Bobot & $\begin{array}{c}\text { Luas } \\
\text { (ha) }\end{array}$ & $\begin{array}{c}\text { Persentase } \\
\text { (\%) }\end{array}$ \\
\hline 1. & $0-200$ & 0,506 & 12,56 & 1,21 \\
2. & $201-300$ & 0,263 & 15,69 & 1,51 \\
3. & $301-400$ & 0,128 & 22 & 2,12 \\
4. & $401-500$ & 0,062 & 28,22 & 2,72 \\
5. & $>500$ & 0,041 & 958,69 & 92,43 \\
\hline & Jumlah & $\mathbf{1}$ & $\mathbf{1 0 3 7 , 1 6}$ & $\mathbf{1 0 0}$ \\
\hline
\end{tabular}

Tabel 3.8 Bobot, luas, dan persentase sub-sub-kriteria jarak dari Puncak Joglo

\begin{tabular}{clccc}
\hline No. & $\begin{array}{c}\text { Jarak dari } \\
\text { Puncak Joglo } \\
\text { (m) }\end{array}$ & Bobot & $\begin{array}{c}\text { Luas } \\
\text { (ha) }\end{array}$ & $\begin{array}{c}\text { Persentase } \\
\text { (\%) }\end{array}$ \\
\hline 1. & $0-200$ & 0,506 & 12,58 & 1,21 \\
2. & $201-300$ & 0,263 & 15,7 & 1,51 \\
3. & $301-400$ & 0,128 & 21,97 & 2,12 \\
4. & $401-500$ & 0,062 & 28,3 & 2,73 \\
5. & $>500$ & 0,041 & 958,62 & 92,43 \\
\hline & Jumlah & $\mathbf{1}$ & $\mathbf{1 0 3 7 , 1 6}$ & $\mathbf{1 0 0}$ \\
\hline
\end{tabular}

Tabel 3.9 Bobot, luas, dan persentase sub-sub-kriteria jarak dari Menara Pandang

\begin{tabular}{clccc}
\hline No. & $\begin{array}{c}\text { Jarak dari } \\
\text { Menara } \\
\text { Pandang (m) }\end{array}$ & Bobot & $\begin{array}{c}\text { Luas } \\
\text { (ha) }\end{array}$ & $\begin{array}{c}\text { Persentase } \\
\text { (\%) }\end{array}$ \\
\hline 1. & $0-200$ & 0,506 & 12,53 & 1,21 \\
2. & $201-300$ & 0,263 & 14,22 & 1,37 \\
3. & $301-400$ & 0,128 & 16,78 & 1,62 \\
4. & $401-500$ & 0,062 & 19,98 & 1,93 \\
5. & $>500$ & 0,041 & 973,64 & 93,88 \\
\hline & Jumlah & $\mathbf{1}$ & $\mathbf{1 0 3 7 , 1 6}$ & $\mathbf{1 0 0}$ \\
\hline
\end{tabular}

Tabel 3.10 Luas persentase kriteria jarak dari objek wisata

\begin{tabular}{clccc}
\hline No. & $\begin{array}{c}\text { Kategori } \\
\text { jarak }\end{array}$ & $\begin{array}{c}\text { Rentang nilai } \\
\text { bobot }\end{array}$ & $\begin{array}{c}\text { Luas } \\
\text { (ha) }\end{array}$ & $\begin{array}{c}\text { Persentase } \\
\text { (\%) }\end{array}$ \\
\hline 1. & Dekat & $0,222-0,312$ & 11,92 & 1,15 \\
2. & Sedang & $0,131-0,222$ & 26,19 & 2,52 \\
3. & Jauh & $0,041-0,131$ & 999,05 & 96,33 \\
\hline & Jumlah & $\mathbf{1}$ & $\mathbf{1 0 3 7 , 1 6}$ & $\mathbf{1 0 0}$ \\
\hline
\end{tabular}

Kriteria yang menjadi prioritas nomor empat dengan bobot 0,114 yaitu kriteria bahwa lokasi homestay dapat diakses oleh berbagai transportasi. Kriteria ini terkait dengan jarak homestay terhadap jalan yang terdapat di Desa Sendang. Semakin dekat lokasi homestay dengan jalan, maka akan mempermudah mobilitas wisatawan. Sebaliknya, lokasi homestay yang jauh dari jalan akan mempersulit mobilitas wisatawan. Karena alasan tersebut, semakin dekat jarak homestay dengan jalan akan memiliki nilai bobot yang semakin besar, begitupun sebaliknya. Pada penelitian ini, kriteria lokasi homestay dapat diakses 
oleh berbagai transportasi dibagi ke dalam 4 sub-kriteria berdasarkan wawancara dengan sekretaris desa Desa Sendang. Sub-kriteria tersebut beserta bobotnya dapat dilihat pada Tabel 3.11.

Tabel 3.11 Bobot, luas, dan persentase kriteria lokasi homestay dapat diakses oleh berbagai transportasi

\begin{tabular}{clccc}
\hline No. & Jarak (m) & Bobot & $\begin{array}{c}\text { Luas } \\
\text { (ha) }\end{array}$ & $\begin{array}{c}\text { Persentase } \\
\text { (\%) }\end{array}$ \\
\hline 1. & $0-50$ & 0,588 & 302,13 & 29,13 \\
2. & $51-100$ & 0,252 & 183,41 & 17,68 \\
3. & $101-200$ & 0,109 & 213,68 & 20,6 \\
4. & $>200$ & 0,052 & 337,94 & 32,58 \\
\hline & Jumlah & $\mathbf{1}$ & $\mathbf{1 0 3 7 , 1 6}$ & $\mathbf{1 0 0}$ \\
\hline
\end{tabular}

Kriteria yang menjadi prioritas nomor lima dengan bobot 0,037 yaitu kriteria bahwa lokasi homestay bebas dari tempat perkembangbiakan nyamuk. Kriteria ini terkait dengan kondisi drainase yang terdapat di Desa Sendang. Kriteria ini dibagi ke dalam 3 sub-kriteria berdasarkan penelitian Umar dkk. (2017) dan rasio konsistensi yang didapatkan yaitu sebesar 0,02. Secara alamiah, kondisi baik/buruknya suatu drainase tergantung dari kemiringan lerengnya. Klasifikasi kemiringan lereng yang digunakan untuk membuat sub-kriteria drainase ini mengacu pada Zuidam (1985) dalam Triandanu et al. (2016). Klasifikasi ini berbeda dengan klasifikasi kemiringan lereng untuk menentukan kerawanan struktur terhadap tanah longsor. Hal ini dikarenakan, saat menentukan kerawanan struktur, yang digunakan adalah klasifikasi kemiringan lereng untuk suatu bangunan.

Berdasarkan wawancara AHP, ketiga narasumber menyebutkan bahwa Desa Sendang merupakan desa yang secara alamiah memiliki drainase yang baik. Hal ini dikarenakan kemiringan lereng di Desa Sendang yang landai hingga curam. Oleh karena itu, kriteria ini menjadi prioritas nomor lima atau terakhir. Sub-kriteria drainase dan bobotnya dapat dilihat pada Tabel 3.12.

Tabel 3.12 Bobot, luas, dan persentase kriteria bebas dari tempat perkembangbiakan nyamuk

\begin{tabular}{rrrlccc}
\hline No & Slope & Ket. & Kondisi & Bobot & $\begin{array}{c}\text { Luas } \\
\text { (ha) }\end{array}$ & $\begin{array}{c}\text { Perse } \\
\text { ntase } \\
\text { (\%) }\end{array}$ \\
\hline 1 & $>7 \%$ & Curam & $\begin{array}{l}\text { Baik sampai } \\
\text { sangat baik }\end{array}$ & 0,769 & 1,76 & 0,17 \\
2 & $2-7 \%$ & Landai & $\begin{array}{l}\text { Sedang } \\
\text { Buruk } \\
\text { sampai } \\
\text { terhambat }\end{array}$ & 0,147 & 21,45 & 2,07 \\
3 & $0-2 \%$ & Datar & $\begin{array}{c}1013, \\
95\end{array}$ & 97,76 \\
\hline & & Jumlah & $\mathbf{1}$ & $\begin{array}{c}\mathbf{1 0 3 7} \\
\mathbf{1 6}\end{array}$ & $\mathbf{1 0 0}$ \\
\hline
\end{tabular}

\subsection{Analisis SIG untuk Penentuan Lokasi Homestay Wisata}

Proses overlay antar raster kriteria akan menghasilkan raster baru yang di setiap pikselnya memiliki total nilai akhir bobot dari 0,171 - 0,761. Total nilai akhir bobot tersebut digunakan untuk menentukan kategori kesesuaian yang dikelompokkan menjadi 4 kelas dengan metode equal interval. Metode ini akan membuat kelaskelas kesesuaian yang memiliki rentang nilai dengan interval sama. Semakin besar total nilai akhir bobot, maka suatu lahan semakin sesuai untuk menjadi lokasi homestay, begitupun sebaliknya. Nilai total bobot, luas, dan persentase dari setiap kategori kesesuaian lahan dapat dilihat pada Tabel 3.13

Tabel 3.13 Rentang nilai total bobot, luas, dan persentase dari setiap kategori kesesuaian lahan

\begin{tabular}{|c|c|c|c|c|}
\hline No. & $\begin{array}{c}\begin{array}{c}\text { Kategori } \\
\text { kesesuaian }\end{array} \\
\end{array}$ & $\begin{array}{c}\text { Rentang } \\
\text { nilai }\end{array}$ & $\begin{array}{l}\text { Luas } \\
\text { (ha) }\end{array}$ & $\begin{array}{c}\text { Persentase } \\
(\%)\end{array}$ \\
\hline 1. & $\begin{array}{l}\text { Sangat } \\
\text { sesuai (S1) }\end{array}$ & $\begin{array}{c}0,614- \\
0,761\end{array}$ & 120,51 & 11,62 \\
\hline 2. & $\begin{array}{l}\text { Cukup } \\
\text { sesuai (S2) }\end{array}$ & $\begin{array}{c}0,466- \\
0,614\end{array}$ & 125,56 & 12,11 \\
\hline 3. & $\begin{array}{l}\text { Sesuai } \\
\text { marjinal } \\
\text { (S3) }\end{array}$ & $\begin{array}{c}0,319- \\
0,466\end{array}$ & 3,1 & 0,3 \\
\hline 4. & $\begin{array}{l}\text { Tidak sesuai } \\
\text { (N) }\end{array}$ & $\begin{array}{c}0,171- \\
0,319\end{array}$ & 787,99 & 75,98 \\
\hline & & Jumlah & 1037,16 & 100 \\
\hline
\end{tabular}

Kategori kesesuaian pertama adalah tidak sesuai $(\mathrm{N})$ dengan rentang nilai total bobot 0,171 - 0,319. Lahan ini merupakan lahan yang tidak boleh digunakan untuk lokasi homestay karena dapat merusak kelestarian dan merupakan lokasi yang berbahaya/tidak aman. Lahan yang tidak sesuai ini berada pada penggunaan lahan nonpermukiman. Selain itu, lahan ini juga tersebar pada daerah yang sangat rawan, rawan, dan cukup rawan terhadap bencana tanah longsor. Lahan yang tidak sesuai ini memiliki luas total 787,99 hektar atau setara dengan $75,98 \%$ dari total luas Desa Sendang. Lahan yang tidak sesuai ini ditunjukkan dengan warna merah pada Gambar 3.1.

Kategori kesesuaian selanjutnya adalah kurang sesuai (S3). Lahan yang kurang sesuai untuk lokasi homestay wisata menunjukkan bahwa lahan memiliki banyak faktor pembatas untuk digunakan sebagai lokasi homestay. Lahan yang kurang sesuai ini dapat digunakan sebagai lokasi homestay wisata namun perlu dipertimbangkan dampak yang akan ditimbulkan serta upaya penanggulangannya. Selain itu, jika lahan ini digunakan sebagai lokasi homestay, biaya yang harus dikeluarkan juga tidak sedikit. Lahan yang kurang sesuai ini memiliki luas 3,1 hektar atau sekitar 0,3\% dari total luas Desa Sendang. Lahan ini seluruhnya berada pada penggunaan lahan nonpermukiman. Dan berada di daerah yang aman hingga cukup aman terhadap bencana. Lahan yang kurang sesuai ini ditunjukkan dengan warna kuning pada Gambar 3.1.

Kategori kesesuaian selanjutnya adalah cukup sesuai (S2). Lahan yang cukup sesuai untuk lokasi homestay wisata menunjukkan bahwa lahan memiliki faktor 
pembatas yang cukup banyak jika digunakan sebagai lokasi homestay. Walaupun faktor pembatas pada lahan S2 tidak memberikan pengaruh yang lebih besar dibandingkan dengan lahan S3, namun tetap perlu dipertimbangkan dampak yang akan ditimbulkan serta upaya penanggulangannya. Lahan yang cukup sesuai ini seluruhnya berada pada lahan permukiman yang sangat rawan, rawan, dan cukup rawan terhadap bencana. Lahan yang cukup sesuai ini memiliki luas 125,56 hektar atau setara dengan 12,11\% dari total luas Desa Sendang. Lahan yang cukup sesuai ditunjukkan oleh warna cokelat muda pada Gambar 3.1.

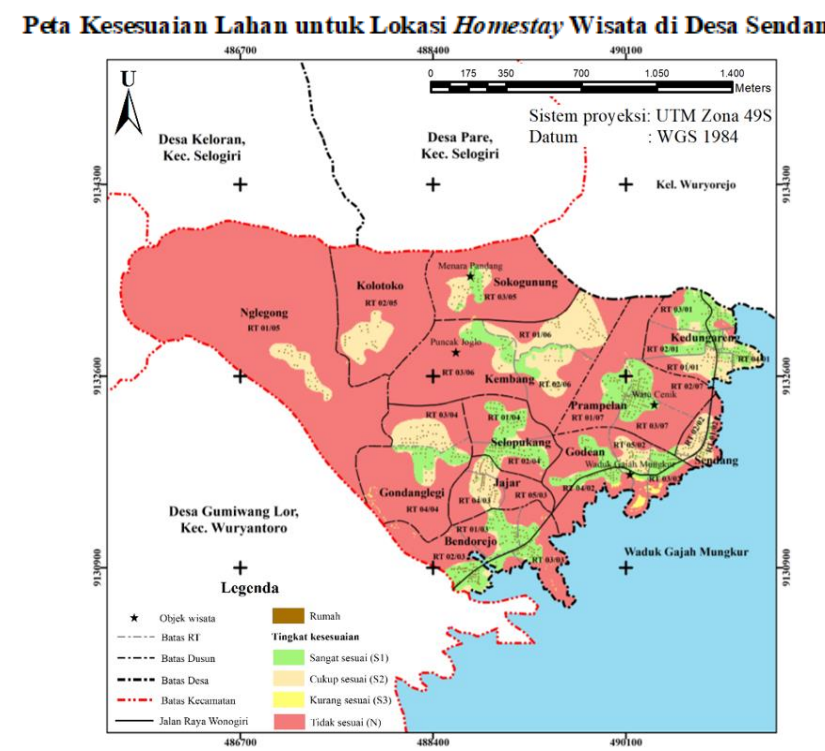

Gambar 3.1. Peta kesesuaian lahan untuk homestay wisata

Kategori kesesuaian selanjutnya adalah sangat sesuai (S1). Lahan yang sangat sesuai ini dapat digunakan sebagai lokasi homestay wisata karena lahan tidak memiliki faktor pembatas yang berarti untuk digunakan sebagai lokasi homestay. Lahan ini tersebar pada lahan permukiman dan tidak berada pada lahan yang sangat rawan terhadap bencana. Lahan ini tersebar di banyak RT dan beberapa memiliki jarak 0 - 200 meter dari setiap objek wisata. Lahan ini juga 95,31\% nya tersebar pada jarak 0 - 50 meter dari jalan. Lahan yang sangat sesuai ini memiliki luas 120,51 hektar atau setara dengan 11,62\% dari total luas Desa Sendang. Lahan ini ditunjukkan oleh warna hijau pada Gambar 3.1.

Pada Gambar III.1 dapat dilihat bahwa lahan yang sangat sesuai tersebar di berbagai lokasi di Desa Sendang. Pada lahan tersebut terdapat 563 dari 923 rumah di Desa Sendang. Tabel 3.14 menunjukkan daftar RT yang memiliki lahan sesuai, luasnya, persentasenya, dan jumlah rumah yang terdapat pada lahan sesuai di setiap RT.

\subsection{Overlay dengan Peta RTRW}

Lahan yang tergolong sangat sesuai (S1) untuk lokasi homestay berdasarkan hasil overlay antar kriteria belum tentu berada pada lahan yang juga sesuai menurut Peta
RTRW dari Peraturan Daerah Kabupaten Wonigiri Nomor 9 Tahun 2011. Oleh karena itu, lahan yang sangat sesuai (S1) kemudian harus di-overlay dengan Peta RTRW. Hal ini dilakukan untuk mendapatkan lahan S1 yang juga diperuntukkan sebagai kawasan permukiman pada Peta RTRW. Proses overlay menghasilkan dua kategori kesesuaian yaitu sesuai dan tidak sesuai.

Tabel 3.14 Lokasi lahan S1, luas, dan persentasenya

\begin{tabular}{clccccc}
\hline No & Dusun & RT & RW & $\begin{array}{c}\text { Luas } \\
\text { (ha) }\end{array}$ & $\begin{array}{c}\text { Persen } \\
\text { tase } \\
\text { (\%) }\end{array}$ & $\begin{array}{c}\text { Jumlah } \\
\text { rumah }\end{array}$ \\
\hline 1 & Bendorejo & 1 & 3 & 7,1 & 5,89 & 34 \\
2 & Bendorejo & 2 & 3 & 9,37 & 7,78 & 44 \\
3 & Bendorejo & 3 & 3 & 6,19 & 5,14 & 37 \\
4 & Godean & 3 & 2 & 5,66 & 4,7 & 34 \\
5 & Godean & 4 & 2 & 11,01 & 9,14 & 46 \\
6 & Godean & 5 & 2 & 1,91 & 1,58 & 7 \\
7 & Gondanglegi & 4 & 4 & 8,47 & 7,03 & 25 \\
8 & Jajar & 4 & 3 & 0,14 & 0,12 & 0 \\
9 & Jajar & 5 & 3 & 0,39 & 0,32 & 5 \\
10 & Kedungareng & 1 & 1 & 0,88 & 0,73 & 1 \\
11 & Kedungareng & 2 & 1 & 6,8 & 5,64 & 29 \\
12 & Kedungareng & 3 & 1 & 11,59 & 9,62 & 35 \\
13 & Kedungareng & 4 & 1 & 3,19 & 2,65 & 34 \\
14 & Kembang & 1 & 6 & 0,01 & 0,01 & 0 \\
15 & Kembang & 2 & 6 & 4,3 & 3,57 & 3 \\
16 & Kembang & 3 & 6 & 6,85 & 5,68 & 14 \\
17 & Nglegong & 1 & 5 & 0,02 & 0,02 & 0 \\
18 & Prampelan & 1 & 7 & 6,01 & 4,99 & 27 \\
19 & Prampelan & 2 & 7 & 5,65 & 4,69 & 43 \\
20 & Prampelan & 3 & 7 & 6,05 & 5,02 & 45 \\
21 & Selopukang & 1 & 4 & 7,78 & 6,46 & 33 \\
22 & Selopukang & 2 & 4 & 6,99 & 5,80 & 46 \\
23 & Sendang & 1 & 2 & 0,4 & 0,33 & 3 \\
24 & Sokogunung & 3 & 5 & 3,75 & 3,11 & 18 \\
& & Jumlah & $\mathbf{1 2 0 , 5 1}$ & $\mathbf{1 0 0}$ & $\mathbf{5 6 3}$ \\
\hline
\end{tabular}

Peta RTRW ini terakhir dilakukan pembaharuan pada tahun 2019, sehingga kedua kategori kesesuaian tersebut adalah kesesuaian dari hasil analisis di tahun 2020 jika dibandingkan dengan rencana pada tahun 2019. Kategori sesuai memiliki luas 68,8 hektar atau setara dengan 6,63\% dari luas total Desa Sendang. Kategori tidak sesuai memiliki luas 968,36 hektar atau setara dengan 93,37\% dari luas total Desa Sendang. Kategori kesesuaian, luas, dan persentase dari hasil overlay lahan S1 dengan Peta RTRW dapat dilihat pada Tabel 3.15. Gambar persebaran lokasi yang sesuai untuk homestay wisata di Desa Sendang berdasarkan overlay lahan S1 dengan Peta RTRW dapat dilihat pada Gambar 3.2.

Dapat dilihat pada Gambar III.2 bahwa lahan yang sesuai ditunjukkan dengan warna hijau. Lahan yang sesuai ini tersebar di berbagai lokasi di Desa Sendang. Pada lahan sesuai, terdapat 420 dari total 923 rumah di Desa Sendang. Tabel 3.16 menunjukkan daftar RT yang memiliki lahan sesuai, luasnya dalam hektar, persentasenya, dan jumlah rumah yang terdapat pada lahan sesuai di setiap RT. 
Tabel 3.15 Hasil overlay lahan S1 dengan Peta RTRW

\begin{tabular}{|c|c|c|c|}
\hline No. & Kategori & Luas (ha) & Persentase (\%) \\
\hline 1. & Sesuai & 68,8 & 6,63 \\
\hline 2. & Tidak sesuai & 968,36 & 93,37 \\
\hline & Jumlah & 1037,16 & 100 \\
\hline
\end{tabular}

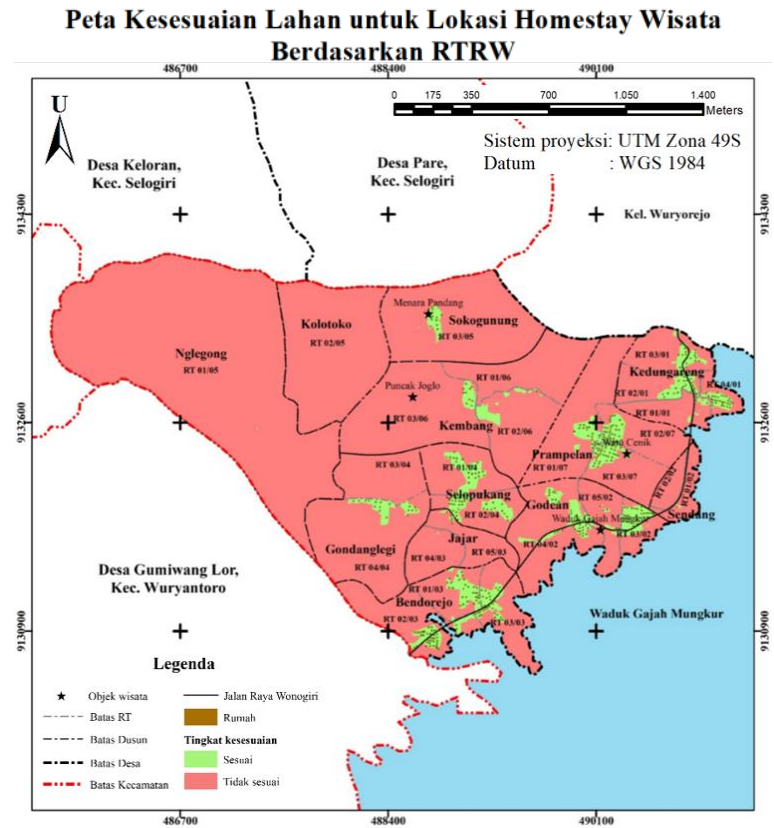

Gambar 3.2. Peta kesesuaian lahan untuk lokasi homestay wisata berdasarkan RTRW

Tabel 3.16 Daftar lahan sesuai berdasarkan Peta RTRW

\begin{tabular}{|c|l|c|c|c|c|c|}
\hline No & \multicolumn{1}{|c|}{ Dusun } & RT & RW & $\begin{array}{c}\text { Luas } \\
\text { (ha) }\end{array}$ & $\begin{array}{c}\text { Persen } \\
\text { tase }\end{array}$ & $\begin{array}{c}\text { Jumlah } \\
\text { rumah }\end{array}$ \\
\hline 1 & Bendorejo & 1 & 3 & 4,73 & 6,88 & 30 \\
\hline 2 & Bendorejo & 2 & 3 & 4,69 & 6,82 & 37 \\
\hline 3 & Bendorejo & 3 & 3 & 4,15 & 6,03 & 29 \\
\hline 4 & Godean & 3 & 2 & 4,79 & 6,96 & 34 \\
\hline 5 & Godean & 4 & 2 & 6 & 8,72 & 36 \\
\hline 6 & Godean & 5 & 2 & 1,11 & 1,61 & 6 \\
\hline 7 & Gondanglegi & 4 & 4 & 4,03 & 5,86 & 17 \\
\hline 8 & Jajar & 4 & 3 & 0,04 & 0,06 & 0 \\
\hline 9 & Jajar & 5 & 3 & 0,33 & 0,48 & 5 \\
\hline 10 & Kedungareng & 1 & 1 & 0,77 & 1,12 & 3 \\
\hline 11 & Kedungareng & 2 & 1 & 3,91 & 5,68 & 21 \\
\hline 12 & Kedungareng & 3 & 1 & 3,14 & 4,56 & 17 \\
\hline 13 & Kedungareng & 4 & 1 & 2,43 & 3,53 & 31 \\
\hline 14 & Kembang & 2 & 6 & 2,7 & 3,92 & 1 \\
\hline 15 & Kembang & 3 & 6 & 2,12 & 3,08 & 10 \\
\hline 16 & Nglegong & 1 & 5 & 0,01 & 0,02 & 0 \\
\hline 17 & Prampelan & 1 & 7 & 3,43 & 4,99 & 21 \\
\hline 18 & Prampelan & 2 & 7 & 3,68 & 5,35 & 39 \\
\hline 19 & Prampelan & 3 & 7 & 4,06 & 5,9 & 42 \\
\hline 20 & Selopukang & 1 & 4 & 5,17 & 7,52 & 21 \\
\hline 21 & Selopukang & 2 & 4 & 4,94 & 7,18 & 35 \\
\hline 22 & Sendang & 1 & 2 & 0,17 & 0,25 & 1 \\
\hline 23 & Sokogunung & 3 & 5 & 2,4 & 3,49 & 14 \\
\hline & & Jumlah & $\mathbf{6 8 , 8}$ & $\mathbf{1 0 0}$ & $\mathbf{4 2 0}$ \\
\hline
\end{tabular}

\section{Kesimpulan}

Berdasarkan penelitian yang telah dilakukan, maka didapatkan kesimpulan bahwa SIG yang dipadukan dengan AHP mampu menganalisis kesesuaian lahan untuk digunakan sebagai lokasi homestay di Desa Sendang dan menghasilkan 4 kelas kesesuaian lahan, yaitu S1, S2, S3, dan N. AHP sendiri berguna untuk menentukan tingkatan kepentingan dari kriteria yang digunakan. Berdasarkan pembobotan metode AHP, syarat/kriteria yang berada pada tingkatan pertama adalah penggunaan lahan. Di tingkat kedua, terdapat kriteria struktur homestay harus berada pada kondisi yang baik, stabil, dan aman. Di tingkat ketiga, terdapat kriteria jarak homestay terhadap objek wisata. Di tingkat keempat, terdapat kriteria lokasi homestay dapat diakses oleh berbagai transportasi. Di tingkat terakhir, terdapat kriteria bahwa lokasi homestay terbebas dari tempat perkembangbiakan nyamuk (khususnya Aedes sp). Kemudian, dari analisis SIG metode AHP, diketahui bahwa lahan-lahan yang sesuai/S1 untuk lokasi homestay tersebar pada 24 RT di 11 dusun dengan luas total 120,51 hektar. Jika lahan-lahan tersebut dioverlay dengan Peta RTRW, maka terjadi pengurangan lahan sesuai dan menjadikan 1 RT tidak sesuai. Hal ini menyebabkan lahan-lahan yang sesuai berdasarkan Peta RTRW hanya terdapat di 23 RT pada 11 dusun dengan luas total 68,8 hektar.

\section{Pernyataan Konflik Kepentingan}

Dalam artikel ini penulis menyatakan tidak ada konflik kepentingan.

\section{Referensi}

Adiyaksa, F. \& Nugroho, P. D. (2020). Evaluasi Alih Fungsi Lahan Pertanian Menjadi Lahan Industri di Kabupaten Kendal Tahun 2014 - 2018. JGISE: Journal of Geospatial Information Science and Engineering Vol.
3 ,
No.1,
(2020),
pp.71-78.

https://doi.org/10.22146/igise.55519

ASEAN. (2016). Asean Homestay Standard. Jakarta.

Astrisele, A. \& Santosa, P. B. (2019). Estimating Land Value Change Post Land Consolidation of Gadingsari Village, Bantul Regency, Special Region of Yogyakarta, Indonesia. JGISE: Journal of Geospatial Information Science and Engineering. Vol. 2 No. 2. https://doi.org/10.22146/igise.51309

Bachri, S. (2011). Analisis daerah rawan longsor untuk penataan penggunaan lahan. Pendidikan Geografi, 16(1),

33-40. https://doi.org/10.17977/pg.v16i1.5542

Bhushan, N., \& Rai, K. (2004). Strategic decision making applying the analytic hierarchy process. SpringerVerlag London.

Evita, R., Sirtha, I. N., \& Sunartha, I. N. (2012). Dampak perkembangan pembangunan sarana akomodasi wisata terhadap pariwisata berkelanjutan di bali. Jurnal Ilmiah Pariwisata, 2(1), 109-222. 
Hidayati, P. F., Kahar, S., \& Subiyanto, S. (2015). Evaluasi kesesuaian lahan permukiman berbasis Sistem Informasi Geografis (Studi Kasus: Semarang bagian Selatan). Jurnal Geodesi Undip, 4(2), 248-255.

Kadriansari, R., Subiyanto, S., \& Sudarsono, B. (2017). Analisis kesesuaian lahan permukiman dengan data citra resolusi menengah menggunakan Sistem Informasi Geografis (Studi Kasus : Semarang bagian Barat dan Semarang bagian Timur). Jurnal Geodesi Undip, 6(4), 199-207.

Nandi. (2007). Longsor. Jurusan Pendidikan Geografi FPIPS UPI.

Oksaping, A. F., Djurdjani, dan Nugroho, P. (2019). Land Valuation with Analytical Hierarchy Process and Regression Method in Grogol Sub-District, Sukoharjo District. JGISE: Journal of Geospatial Information Science and Engineering. Vol. 2 No. 1. https://doi.org/10.22146/igise.40845

Pahlavani, P., Sheikhian, H., \& Bigdeli, B. (2017). Assessment of an air pollution monitoring network to generate urban air pollution maps using Shannon information index, fuzzy overlay, and DempsterShafer theory, A case study: Tehran, Iran. Atmospheric Environment, 167, 254-269. https://doi.org/10.1016/j.atmosenv.2017.08.039

Parry, J. A., Ganaie, S. A., \& Bhat, M. S. (2018). GIS based land suitability analysis using AHP model for urban services planning in Srinagar and Jammu urban centers of J\&K, India. Journal of Urban Management, $7(2)$, https://doi.org/10.1016/j.jum.2018.05.002

Pemerintah Desa Sendang. (2019). Selayang Pandang Desa Sendang. Wonogiri.

Petriella, Y. (2019). Kementerian Pariwisata Rumuskan Pajak Homestay Yang Ideal, Diusulkan 1\%. Diambil dari Bisnis.com website: https://ekonomi.bisnis.com/read/20190221/12/89 1971/kementerian-pariwisata-rumuskan-pajakhomestay-yang-ideal-diusulkan-1

Prafitri, G. R., \& Damayanti, M. (2016). Kapasitas Kelembagaan Dalam Pengembangan Desa Wisata (Studi Kasus: Desa Wisata Ketenger, Banyumas). Jurnal Pengembangan Kota, 4(1), 76-86. https://doi.org/10.14710/jpk.4.1.76-86

Raharjana, D. T. (2012). Membangun pariwisata bersama rakyat: kajian partisipasi lokal dalam membangun desa wisata di Dieng Plateau. Kawistara, 2(3), 225237. https://doi.org/10.22146/kawistara.3935

Saaty, T. L., \& Vargas, L. G. (2012). Models, methods, concepts \& applications of the analytic hierarchy process (2nd Ed.). Springer Science+Business Media https://doi.org/10.1007/978-1-4614-3597-6

Siagian, T. P., Sudarsono, B., \& Wijaya, A. P. (2016). Evaluasi kriteria kesesuaian lahan permukiman dengan Analitycal Hierarchy Process (Studi Kasus: Kecamatan Boja dan Kecamatan Limbangan di Kabupaten Kendal ). Jurnal Geodesi Undip, 5(1), 107-
115.

Solang, M. W., Mandagi, R. J. M., \& Lumeno, S. S. (2017). Analisis evaluasi kesesuaian lahan perumahan di Kota Manado dengan menggunakan Geographic Information System dan Multiple Criteria Decision Making. Jurnal Ilmiah Media Engineering, 7(4).

Triambodo, S. (2014). Analisis Strategi Penguatan Kelembagaan Desa Wisata Berbasis Ekonomi Kreatif (Studi di Desa Wisata Kerajinan Tenun Dusun Gamplong, Desa Sumberrahayu, Kecamatan Moyudan, Kabupaten Sleman, DIY). Universitas Gadjah Mada.

Triandanu, N., Alfan, I., \& Muslim, D. (2016). Surface Geology Characteristic and Its Influence to Landslide Potential in Cisokan Drainage Pattern, West Bandung, Indonesia. International Journal of Structural and Civil Engineering Research, 5(2), 147-150. https://doi.org/10.18178/ijscer.5.2.147-150

Umar, I., Widiatmaka, Pramudya, B., \& Barus, B. (2017). Evaluasi kesesuaian lahan untuk kawasan permukiman dengan metode Multi Criteria Evaluation di Kota Padang. Jurnal Pengelolaan Sumberdaya Alam dan Lingkungan, 7(2), 148-154. https://doi.org/10.19081/jpsl.2017.7.2.148

Widiyastuti, D., Ermawati, H., Septiawan, L., \& Kumara, I. S. W. (2019). Land Suitability Analysis for Housing in Pesisir Selatan Regency, West Sumatra, Indonesia. ASEAN Journal on Science and Technology for Development, 36(2), 45-52. https://doi.org/10.29037/ajstd.574

Yunus, R. M., Samadi, Z., Yusop, N. M., \& Omar, D. (2013). Expert Choice for Ranking Heritage Streets. Procedia - Social and Behavioral Sciences, 101, 465-475. https://doi.org/10.1016/j.sbspro.2013.07.220 